\title{
THE PATENT PROVISIONS OF THE ATOMIC ENERGY ACT
}

\author{
CASPER W. OOMS*
}

I have said, Mr. President, that it is a challenging subject. It is complicated. Atomic energy can make or destroy America. So, I should like to speak for a few moments about the result of the committee's endeavors and about the bill as it finally shapes up before us. ...

I tried to emphasize to the Senate when I started that the Committee became convinced that this subject wrote its own rules. It writes them out of the sheer necessity that is inherent in this tremendous force. ... I

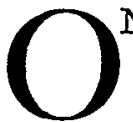

NE of the astonishing contemporary political phenomena is the paucity of patent legislation. With Congress sitting almost uninterruptedly from the beginning to the end of the year, with criticism or suggestions for reform of the patent system recurring in almost every economic treatise that appears, ${ }^{2}$ and with patents remaining one of the most heavily litigated subjects in the federal courts, there is comparatively little patent legislation enacted, and little more reaching the stage of committee report in Congress.

There are doubtless many reasons for this. The subject of patents is considered complex and difficult. Patent reform has little vote-getting appeal. Many of the patent reforms proposed are excessive in their purpose, and accordingly many of the bills drawn to effect them receive no extensive support. These considerations lead to congressional restraint. The inability of any substantial group of interested advocates of patent reform, whether they be lawyers, manufacturers, or merely interested citizens, to agree upon any proposed patent legislation, prevents the formulation of an active program with the broad base of support necessary to sustain congressional interest. And finally, there is always a lobby.

* Member of the Illinois bar, former United States Commissioner of Patents, and member of the Patent Advisory Panel Atomic Energy Commission. The views herein expressed are the personal views of the author and do not pretend to express any official opinions or policy.

× Senator McMahon, presenting S. г717 to the United States Senate, 92 Cong. Rec. 6082, 6086 (June $\mathrm{I}$, I946).

${ }^{2}$ Simons, Economic Policy for a Free Society ror, 248-49 (I948); Bush, Endless Horizons I5 ${ }^{x-69}$ (I946); I Lyon, Watkins, and Abramson, Government and Economic Life 132-5I $^{2}$ (1939); Bliven and Mezerik, What the Informed Citizen Needs to Know 91-I03, I24-39 (I945); Ballinger, By Vote of the People 329-34 (1946); Spencer, United States Patent Law System (r93I). 
In this respect the year I946 was little different from previous years. Nevertheless, in that year the most sweeping patent legislation ever enacted in this country was drafted and approved, almost within the short period of six months. The lobby was there. The active disagreement upon program was more vocal than ever. The political aspects of patent reform were as unpromising as ever. Everything was sufficiently normal to indicate that the proposed patent reforms would suffer customary neglect except that the patent legislation was merely an incident to the Atomic Energy Act. There could be no apathy about that. Only the urgency of atomic energy legislation carried the patent legislation with it.

The patent provisions of the Act as approved are the same as those reported to the Senate by its Committee. In the House of Representatives the proposed Act was amended and the Senate patent provisions displaced with a wholly different section. ${ }^{3}$ In conference the substitution was reversed and the original language drafted by the Senate Committee retained. 4

The novelties presented by the patent provisions of the Atomic Energy Act may be considered in five categories: I) creation of fields in which patents are revoked and future patents prohibited; 2) abolition of patent rights with respect to inventions used in the conduct of research;3) compulsory licensing of patents "affected with the public interest"; 4) purchase or condemnation of inventions and patents; and 5) administrative innovations with respect to patents.

\section{CREATION OF FIELDS IN WHICH PATENTS ARE REVOKED AND FUTURE PATENTS PROHIBITED}

The most sweeping patent provisions in the Atomic Energy Act are those dealing with the elimination from the field of patentable invention of all inventions "useful solely in the production of fissionable material or in the utilization of fissionable material or atomic energy for a military weapon." The Act not only forbids the issuance of patents for inventions of this character, and the acquisition of rights under any patents to the extent that the inventions covered by the patents are "used in the production of fissionable material or in the utilization of fissionable material or atomic energy for a military weapon," but revokes all issued patents and patent rights within the prohibited fields, and provides for the payment of just compensation therefor. ${ }^{5}$

The statute thus introduced an exception to the enumerated classes of

${ }^{3} 92$ Cong. Rec. 96 xx (July 19, $x 946$ ).

4 Ibid., at ror 56-57 (July 25, x946).

$s 60$ Stat. 768 (I946), 42 U.S.C.A. § $18 \mathrm{II}(\mathrm{a})$ (I) (Supp., I947). 
patentable subject matter in the Patent Act, there defined as "any new and useful art, machine, manufacture, or composition of matter, or any new and useful improvements thereof." in identical terminology since the Act of $1793 .{ }^{7}$ Design patents had been provided for in $1842,{ }^{8}$ and patents for certain asexually reproduced plants in $1930 .{ }^{9}$

The categories of patentable subject matter thus long recognized in the United States patent laws, while embracing the majority of industrially applicable inventions, nevertheless leave vast areas of inventive effort beyond the embrace of the law. Patents may not be granted for scientific discoveries, ${ }^{\text {To }}$ although recognition of that more fundamental type of contribution has been advocated almost throughout the world. ${ }^{\text {xI }}$ Even processed fruits, such as oranges treated with mold inhibiting solutions', have been held to be beyond the statute. ${ }^{12}$ Similarly excluded are methods of doing business, ${ }^{{ }_{3}}$ printed forms, ${ }^{{ }^{4}}$ and other economically useful contrivances.

In foreign countries there are other specific exclusions, varying from country to country, and including such diverse matters as textile processes, systems of labor, secrets of factories, schemes of finance and credit, systems of ciphering, methods of teaching, human or animal food, beverages, pharmaceutical compositions, medicines, chemical products, etc. ${ }^{15}$

The selection of the subject matter to be included within or excluded from the fields in which patents will be granted is merely an expression of the contemporary public policy, and expectedly varies with the times and local political attitudes.

The conditions which led to the exclusions expressed in Section II (a) (I) of the Atomic Energy Act were expressed in the Act, which made it ${ }^{6} 29$ Stat. 692 (I897), as amended, 35 U.S.C.A. \& 3 I (1940).

7 I Stat. 318, \& I (I793).

${ }^{8} 5$ Stat. $543, \S 3$ ( 1842$)$.

${ }^{9} 46$ Stat. 376 ( 1930 ), 35 U.S.C.A. $\S 40$ (1940).

ro Funk Brothers Seed Co. v. Kalo Inoculant Co., 333 U.S. I27 (1948).

Ir Hamson, Patent Rights for Scientific Discoveries (r930); see Report of the Committee on Patents, Copyrights and Trade Marks of the American Association for the Advancement of Science (1934).

${ }^{12}$ American Fruit Growers, Inc. v. Brogdex Co., 283 U.S. I (193I).

${ }^{23}$ Hotel Security Checking Co. v. Lorraine Co., I6o Fed. 467 (C.C.A. 2d, I908).

${ }^{14}$ Conover v. Coe, 99 F. $2 \mathrm{~d} 377$ (App. D.C., I938); In re Sterling, 70 F. $2 \mathrm{~d}$ 910 (C.C.P.A., 1934).

${ }^{25}$ Ladas, The International Protection of Industrial Property 22I-27 (I930); Vojacek, A Survey of the Principal National Patent Systems I6-I9 (I936); Federico, Patents for New Chemical Compounds, 2I J. Pat. Off. Soc. 544 (I939). 
unlawful for any person to manufacture, produce or refine fissionable material, or to own any facilities for that purpose. The Atomic Energy Commission, created by the Act, was made owner of all such facilities other than those of limited capacity useful in the conduct of research and development in the fields of nuclear processes, atomic energy, and the utilization of fissionable and radioactive materials. ${ }^{16}$

The Act had invested the Atomic Energy Commission with all property rights in all fissionable materials, whenever produced, and had made private ownership or dealing in such materials unlawful. ${ }^{17}$

In addition the Act had declared it unlawful for any person to manufacture, deal in, or acquire any device using fissionable material or atomic energy as a military weapon, except as authorized by the Commission, to which had been intrusted the conduct of all experiments, research, and development in the military applications of atomic energy in accordance with such directions as the President might give the Commission and the armed forces. ${ }^{18}$

The purpose of these provisions, wrought at a time when most nations were sincerely concerned with a vigorous attempt to fashion acceptable international control of atomic weapons, was obvious. Congress became convinced of the need for this exceptional treatment in an extended debate in which it considered the extraordinary problems which the military potentialities of atomic energy created, the indispensability of assurance that a weapon of this terrific character would remain under government control, the need for responsible administration of the entire field of atomic energy, military and industrial, and the necessity for the greatest possible secrecy of operations in the field until adequate international control had been effected.

Any such control, to be effective, had to extend throughout the production and utilization of fissionable materials. Any gap in the control would cripple the national commitment. Any nation that could not commit its entire atomic energy program to the common effort of complete control would render effective control impossible.

What was thus inevitable internationally necessarily carried into the domestic economy all the implications that this grant of extensive powers to the Commission involved. It meant a corresponding prohibition to the community at large of the exercise of traditional property rights within the proscribed field. It was a departure from the general principles of

\footnotetext{
${ }^{26} 60$ Stat. 759 (1946), 42 U.S.C.A. $\$$ I804(a) (b) (c) (Supp., ig47).

${ }_{77} 60$ Stat. 760,765 (I946), 42 U.S.C.A. $\$$ I805(a)(2), (3); $\S \mathrm{I809(a)(r)} \mathrm{(Supp.,} \mathrm{I947).}$

${ }^{18} 60$ Stat. 768 (1946), 42 U.S.C.A. $\$$ I806 (Supp., 1947).
} 
property ownership and freedom of conduct without parallel in our history.

It was inescapable that so drastic a revision of accepted concepts of private property in a lively field of technology would leave its impact on the relevant features of the patent system. Had Congress never enacted the prohibitions with respect to the patenting of inventions in the production of fissionable materials or their utilization in atomic weapons, it may be doubted whether the result would have been substantially different.

The patents prohibited and revoked are in the two fields intrusted exclusively to the Commission: those of $\mathrm{r}$ ) production of fissionable materials, and 2) their utilization in military weapons. Industrial activity in these fields having been proscribed to private business, there remained little room for the normal operation of the patent system. Inasmuch as the patent is a mere grant of the power to exclude others from the exer"cise of the patented invention, there were no "others" upon whom the power to exclude could operate. All, patentee and stranger alike, were, by the Act, excluded from the exercise of all activities in the proscribed fields. Only the Commission could exercise any inventions within the fields, and thus only the Commission could feel the restraints which the patentee would be empowered, by the patent grant, to impose. The granting of patents under such circumstances would constitute not only a futile but unnecessarily embarrassing procedure.

These considerations apply with additional vigor to the prohibition of patents upon inventions useful solely in the utilization of fissionable material or atomic energy for military weapons. Not only is there inherently complete control in any well ordered government of the manufacture of military weapons (not always exercised, it is true) but there are many good reasons why the purposes and operations of a patent system frequently contradict the essentials of sound military practices.

One of the objects of a patent system is to induce quick and complete disclosure of the novel technique. Frequently-an observation especially evident with respect to atomic weapons - the very efficacy of the weapon will depend upon its concealment and the maintenance of complete secrecy as to its existence and design. Congress has recognized this conflict of military needs and patent system objectives by special provisions in the patent laws for the delayed prosecution of applications for patents upon inventions "important to the armament or defense of the United States" and for the imposition by the Commissioner of Patents of prohibitions

1929 Stat. 692 (1897), as amended, 35 U.S.C.A. $\$ 37$ (I940). 
against disclosure of the contents of pending applications, and the withholding of the issuance of patents upon inventions where the disclosure thereof might be "detrimental to the public safety or defense."

Several foreign countries meet this difficulty by the creation of "secret patents," a term that inherently announces the frustration of the patent system. ${ }^{2 x}$

Many inventions of military weapons are made by members of the armed services and owned by the government, but are nevertheless patented, for no other reason than to protect the government against the assertion of claims by subsequent inventors for use of the invention by the government.

The elimination of patent rights to inventions in atomic weapons obviates all of these difficulties. The need for secrecy is not hazarded by even the limited disclosure necessary to present and prosecute a patent application, the absurdity of the "secret patent" is avoided, and the nuisance of purely defensive patenting is rendered unnecessary.

The problem is not without its own diffculties, however. The definition of the inventions proscribed must necessarily be arbitrary, and the terminology employed, in view of our limited experience with the entire art of atomic devices, introduces novel questions of interpretation. For example, the Act prohibits patents for inventions "useful solely in the production of fissionable material." Many of the processes involved in the production of fissionable materials are separation processes. A separation process inevitably produces at least two materials. If both are useful and one is fissionable, is the process within the definition? Conceivably so. But suppose the same separation process is equally capable of separating several isotopes, of which none is fissionable, and by a mere variation of the controls involved can be transformed from the one process which meets the definition to one which does not. Obviously by its mere versatility the invention escapes the prohibition against patenting, but falls within the following provision of the statute which disqualifies it pro tanto " to the extent that such invention or discovery is used in the production of fissionable material."

One difficulty readily intrudes. An inventor applies for a patent on a relatively unimportant invention which is within the prohibited area. $\mathrm{He}$ is not aware that the invention has other innocent uses foreign to the definition, and the Patent Office successfully and finally rejects the application. The inventor seeks and secures the statutory award from the

${ }^{20} 40$ Stat. 394 (rgr7), as amended, 35 U.S.C.A. $\$ 42$ (r940).

2x Vojacek, op. cit. supra note 15 , at 42 . 
Commission, and the invention is used on a modest scale. Assume that subsequently, and more than a year after the invention is used publicly, other important uses in unprohibited fields are discovered. No patent can be procured because of the year's use. No provision is found in the statute for any adjustment of a difficulty of this kind.

In addition to the substantive alterations in the patent system achieved by the elimination of the specified types of inventions from application of the patent laws, the Atomic Energy Act introduced requirements as to reporting of inventions, and as to the determination of just compensation for the patents wholly or partially revoked by the Act. ${ }^{22}$ These provisions are discussed in the final section of this paper.

\section{ABOLITION OF PATENT RIGHTS WITH RESPECT TO INVEN- TIONS USED IN THE CONDUCT OF RESEARCH}

Far more sweeping in compass, although much more limited in effect, than the provision abolishing patentability with respect to inventions because of their character, is the provision in the Atomic Energy Act destroying and prohibiting subsequent creation of "any rights with respect to any invention or discovery to the extent that such invention or discovery is used in the conduct of research or development activities in the fields specified in section $3 .{ }^{123}$ Section 3 enumerates the fields of research in which the Commission is directed to encourage and insure continuing research and development in the following encyclopedic catalog:

I. nuclear processes;

2. the theory and production of atomic energy, including processes, materials, and devices related to such production;

3. utilization of fissionable and radioactive materials for medical, biological, health, or military purposes;

4. utilization of fissionable and radioactive materials and processes entailed in the production of such materials for all other purposes, including industrial uses; and 5. the protection of health during research and production activities. ${ }^{24}$

This comprehensive program leaves few fields of industrial activity untouched. As a result, the impact of the provision exempting inventions employed in research from patent dominance may be felt upon patents in many fields. Yet the actual effect upon patent rights may be almost negligible, for few of the patents involved will be so clearly destined for research purposes alone that the patent right can be ignored on the assumption that the manufacture or sale of inventions covered by the patent are inevitably destined for use in the exempted field of research.

For example, a patent upon an invention in cyclotrons might clearly

${ }_{22}^{2} 60$ Stat. 768 (r946), 42 U.S.C.A. § I8II(a)(3), (e) (Supp., I947).

${ }^{23} 60$ Stat. 768 (I946), 42 U.S.C.A. \& I8II(b) (Supp., I947).

${ }^{24} 60$ Stat. 758 (I946), 42 U.S.C.A. $\S$ I803(a) (Supp., I947). 
have no other presently conceivable uses than in research, and the patentee might therefore be denied any right of enforcement. An invention in Geiger counters, on the other hand, clearly has industrial uses apart from the field of research and no manufacturer could enter upon the manufacture of such, or similar testing devices with any assurance that his activity was exempt from the reach of a patent upon the invention. As a result, the normal practices of commerce as to licensing would undoubtedly be followed.

Were the manufacturer a licensee under such a patent, he might raise a question as to his obligation to pay royalties upon devices which were earmarked at the time of sale for research work. And if the patentee sought to license such manufacture and sale and collect royalties on all such devices, independently of the destined use of the patented device, he might run afoul of doctrines announced in recent Supreme Court cases which deprive the patentee of his right to sue for infringement where the patent is used to collect royalties on devices not dominated by the patent claim. ${ }^{25}$

The provision of the Act is drawn sufficiently broadly to exempt from patent coverage all equipment used in the identified field of research. Thus, where vast buildings are erected and extensive machinery installed in plants devoted to nuclear research, everything from the hardware on the windows to large electric motors and the buildings themselves would be free of patent control. While the research enterprise could avail itself of this new freedom and manufacture or procure from unauthorized sources all patented materials employed in the project, it is unlikely that the opportunity will be sufficiently attractive to induce these aberrations from normal commercial practices. While doubtless special equipment required to be built for such a project might be given some slight advantage by release of patent dominance, and a wider variety of sources would become available for such equipment, the likelihood is that those sources which had done the most advanced work in the field would be both the possessors of the patent rights involved and the supplier of such equipment.

A conceivable narrower construction of this provision of the statute also suggests itself, and that is that the field of immunity is narrowed to the actual "conduct of research or development activities," and that only the "use" of the invention in such research is exempt. Inasmuch as the patent confers "the exclusive right to make, use, and vend the invention or discovery" ${ }^{\prime 26}$ the Act may have intended to leave untouched the patentee's

as Mercoid Corp. v. Mid-Continent Investment Co., 320 U.S. 66I (I944); Mercoid Corp. v. Minneapolis-Honeywell Co., 320 U.S. 680 (I944).

${ }^{26} 46$ Stat. 376 (I930), 35 U.S.C.A. $\$ 40$ (I940). 
exclusive right in making and selling the invention. To the extent that the patentee might thus control the availability of patented devices needed in research, the freedom for research might in some instances be curtailed if the procurement by manufacture or purchase from unauthorized sources were subject to the patentee's control, and the immunity of use might be ineffective. If, as appears from the terms of the Act, the purpose of Congress was to encourage research in these fields untrammeled by the remotest possibility of restraint by patent control, the broader interpretation of this provision of the Act must be accepted as the only construction that will insure this objective.

What Congress apparently attempted was the enactment into statutory law of a vaguely recognized principle expressed in a few patent decisions that "an experiment with a patented article for the sole purpose of gratifying a philosophical taste, or curiosity, or for mere amusement [hardly' applicable in considering the problems of atomic energy] is not an infringement of the right of the patentee." ${ }^{27}$ This effect could, of course, have been accomplished by suitable provisions for restricted compulsory licensing, with only the additional administrative burden which that might have imposed, except that the Atomic Energy Act clearly manifests a purpose to render research and development as free as possible from control by the Commission..$^{28}$

Although the section of the Act which frees research activities from any liability for patent infringement effects an actual revocation of patent rights, and pro tanto forbids the procuring in the future of patent rights upon any invention so employed, and the Act provides for just compensation to the owner of such rights in issued patents, it makes no provision for payment of an award of any kind to the inventor whose patent may issue in the future for an invention that may be utilized in research. This is in contrast to the provisions entitling the owners of inventions in production of fissionable materials and their utilization in atomic weapons, discussed above, to an award by the Commission.

\section{COMPULSORY LICENSING OF PATENTS DECLARED TO BE AFFECTED WITH THE PUBLIC INTEREST}

Although the Atomic Energy Act does not use the term "compulsory licensing," it does contain a grant of power to the Commission to effect compulsory licensing under patents which the Commission must declare

${ }^{27}$ Dugan v. Lear Avia, Inc., 55 F. Supp. 223 (N.Y., I944), I56 F. 2 d 29 (C.C.A. 2d, I946); Northill Co. v. Danforth, 5 I F. Supp. 928 (Cal., I942), I42 F. 2d 5I (1944); 3 Walker, Patents $\$ 450$ (Deller's ed., I937).

${ }^{28} 60$ Stat. $758,759,764$ (I946), 42 U.S.C.A. $\S$ I803(a); $\$ 1804$ (c) (3), 4 (c); I807(a) (Supp., r947). 
"to be affected with the public interest if (a) the invention or discovery covered by the patent utilizes or is essential in the utilization of fissionable material or atomic energy; and (b) the licensing of such invention or discovery under this subsection is necessary to effectuate the policies and purposes of" the Act. ${ }^{29}$ Thereupon the Commission is automatically licensed to use the invention covered by the declared patent, and any person licensed by the Atomic Energy Commission under Section 7 of the Act to manufacture, produce, or export equipment utilizing fissionable material or atomic energy, or to utilize fissionable material, is automatically licensed to the extent the invention of the declared patent is used by the licensee in conducting the activities licensed under Section $7 .^{30}$

The Act prescribes that the owner of the patent shall be entitled to a reasonable royalty for any use of the invention licensed in this manner, either as agreed upon by the patent owner and licensee or as determined by the Commission, forbids injunctive process against the licensee, and prescribes the manner in which the royalty fee is to be determined by the Commission. ${ }^{3 \mathrm{r}}$

This is obviously compulsory licensing, although restricted in form. It is to be noted that the declaration that the patent is affected with the public interest is conditioned upon the invention's utilization of fissionable material or atomic energy and the need for licensing of the invention to effectuate the policies and purposes of the Atomic Energy Act. Only the first restriction is substantial, as the Act's recitals of its policies and purposes are extremely comprehensive, declaring that "the development and utilization of atomic energy shall, so far as practicable, be directed toward improving the public welfare, increasing the standard of living, strengthening free competition in private enterprise and promoting world peace," and that to effectuate these policies it is the Act's purpose to provide for major programs relating to atomic energy, to assist and foster private research and development, to encourage maximum scientific progress and dissemination of technical information, and to control the production, ownership, and use of fissionable material for the common defense and security, etc. ${ }^{32}$

The first restriction, however, limiting the power of compulsory licensing to patents for inventions utilizing or essential to the utilization of fissionable material or atomic energy practically limits the licensing power to unique devices over which the Commission already has full control

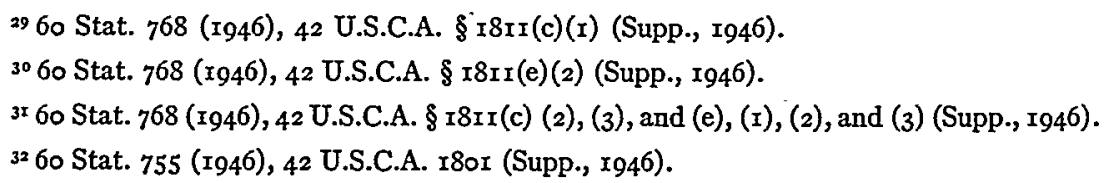


through its licensing power under Section 7. The further restriction in the Act, confining the compulsory patent license to those activities authorized by the license under Section 7 , distinctly narrows the scope of licenses which are available under the patents to which this section is applicable.

Within these limitations it is apparent that what was attempted by this part of the Act was assurance that no license to utilize fissionable materials granted under Section 7, which contains elaborately detailed provisions to insure the granting of such licenses on a nonexclusive and nondiscriminatory basis, would be nullified by a patent owner who might exercise his patent rights on an exclusive and discriminatory basis and thus thwart the purposes of Section 7 .

In view of these limitations it is somewhat surprising that this proposal for compulsory licensing, restricted as it is, evoked the controversy which it did during the debates on the Act. Compulsory licensing in various restricted forms is not new to the American patent system. The government, by statute, has confined the remedy against itself or its contractors for patent infringement on its behalf to a suit for reasonable compensation in the Court of Claims, and has further empowered itself to modify the royalty rates provided for in contracts between patentees and their licensed contractors who may be supplying the government. ${ }^{33}$ Special statutes, such as those creating the Tennessee Valley Authority, have empowered the agency to employ patented inventions subject only to liability for "reasonable compensation for such infringement." 34 The federal courts, by refusal of injunction in cases where the public interest renders injunctive relief inequitable, ${ }^{35}$ or by denying relief where the patent has been employed contrary to public policy,,$^{36}$ have similarly permitted patent infringement without other liability than at most liability for monetary damages, and thus effected involuntary licensing. More directly, in cases where patents have been used in violation of the antitrust laws, the courts have included within the decrees specific provisions for the compulsory licensing of the patents owned by the offending party. ${ }^{37}$

Throughout these statutes and decisions runs the doctrine that the public interest may warrant tempering of the complete power of the pat-

${ }_{33}^{3} 36$ Stat. 85 I (I9I0), as amended, 35 U.S.C.A. \$ 68, 89-96 (I940).

${ }^{34} 48$ Stat. 68 (I933), I6 U.S.C.A. § 83rr. (r94I).

${ }_{35}$ Nerney v. N.Y., N.H. \& H.R. Co., 83 F. 2 d 409 (C.C.A. 2d, x936); City of Milwaukee v. Activated Sludge, Inc., 69 F. 2d 577 (C.C.A. 7 th, 1934).

${ }^{36}$ Morton Salt Co. v. Suppiger, 314 U.S. 488, 490-9x (1942).

37 United States v. National Lead Co., 332 U.S. 3 I9 (I947); Hartford-Empire Co. v. United States, 323 U.S. 386 ( $(945)$; for other cases see 332 U.S. 3I9, 350 n. 9 . 
ent owner to select his licensees and fix the terms of his licenses, a doctrine restated with almost prophetic timeliness in the First Report of the National Patent Planning Commission:

After a study of the needs in this country and the effects in foreign countries of a compulsory licensing system, the Commission has reached the conclusion that it would not be advantageous to incorporate such a general system in our patent laws. However, the Commission is impressed with the need of a degree of compulsion in certain fields, such as national defense, public health, and public safety. While the Commission is unaware of any case in which a court has prohibited the use of an invention covered by a patent when the effect of such prohibition would be injurious to national defense, public health or public safety, nevertheless it is felt that the statutory laws should be so clarified as to remove any possible doubt on the subject.

The Commission therefore recommends a statutory provision that in a suit for infringement the recovery of a patent owner shall be limited to reasonable compensation without prohibiting the use of the patented invention whenever the court finds that the particular use of the invention in controversy is necessary to the national defense or required by the public health or public safety. ${ }^{38}$

It is hardly conceivable that anyone would argue that the operations under licenses from the Atomic Energy Commission are not impressed with considerations of the national security and defense, or public health and safety. All of the licensing by the Commission is compelled by those very considerations. Perhaps some of the operations may have only economic implications, but their potentialities in this field are so enormous that they may transcend simpler considerations of health and safety. ${ }^{39}$

This venture in compulsory licensing will be watched with interest. The power to license involuntarily may never be invoked. Its presence in the statute may insure completely free negotiation of all the licenses that may ever be required. On the other hand, if invoked, it will furnish objective data upon an interminable controversy as to the effects of restricted compulsory licensing upon the incentives attributed to the patent system and upon the protection of initial operations within the monopoly of the patent. If the effects are adverse, the purposes of the Act to encourage the most rapid and extensive development of the nonmilitary potentialities of atomic energy, may to this extent be defeated. In any event, the data will meet a need that economists and legislators have long recognized.

\section{PURCHASE OR CONDEMNATION OF INVENTIONS AND PATENTS}

One final power with respect to patents, doubtless inherent in the government with respect to all property, was intrusted to the Atomic Energy

${ }^{38}$ First Report of the National Patent Planning Commission, The American Patent System IO-II (I943).

39 Hutchins, The Bomb Secret Is Out, I45 American Magazine No. I2, at 24, 134 (Dec., I947); Lilienthal, The Atomic Adventure, I I9 Colliers No. I8, at I2, 82 (May 3, I947). 
Commission. The Commission is authorized to purchase or condemn, subject to liability for just compensation, any invention, or patent or patent application thereon, useful in the production of fissionable material or in the utilization of fissionable material or atomic energy for a military weapon, or utilizing or essential to the utilization of fissionable material or atomic energy..$^{\circ}$

The purpose of this provision is not clear. In view of the broad powers of the Commission with respect to licensing of patents in this field, and the Commission's own right to employ such inventions, little can be gained by the actual acquisition of patents, other than the opportunity to free licensees under Section 7 of any liability for royalties. The United States government has never enforced patents which it acquired, and its proper passivity in this respect has resulted in what is in effect a dedication of the inventions covered by government-owned patents. Under what circumstances the Commission might desire to purchase issued patents under this provision is not apparent.

With respect to inventions not within the proscription as to patentability, other considerations apply. For example, an invention useful for the production of fissionable material, but not solely useful therefor, could be patented. As a matter of security it might appear desirable to purchase the invention to prevent the filing of an application thereon. The possibilities of such a contingency are quite remote. In fact, the possibilities of the appearance of inventions or patents which would invite their purchase or acquisition rather than their employment through the other instruments which the Act provides promise little use of this provision of the Act.

\section{ADMINISTRATIVE INNOVATIONS WITH RESPECT TO PATENTS}

\section{REPORTING PROCEDURES}

In addition to these substantive provisions with respect to patent rights in inventions related to the atomic energy project, the Act introduces a number of administrative innovations that merit consideration.

The first provision of this character is that requiring the inventor of an invention useful in the production of fissionable material or its utilization in a military weapon to report to the Commission a description of the invention, unless a patent application has been filed therefor. The statute fixes the time for the report as the latest of three dates: the sixtieth day after A) enactment of the Act;B) completion of the invention; or C) first

${ }^{40} 60$ Stat. 768 (1946), 42 U.S.C.A. \& I8II(d) (Supp., I946). 
discovery or reasonable belief that the invention is of the character defined. $4^{4}$

Another reporting provision in the statute requires the Commissioner of Patents to notify the Commission of all applications for patents which disclose inventions useful in the production of fissionable material or its utilization in a military weapon, or which utilize or are essential in the utilization of fissionable material or atomic energy, and to provide the Commission with access to all such applications. ${ }^{42}$ This provision departs from the peacetime practice of maintaining all pending patent applications in secrecy, an internal control long imposed by the Rules of Practice of the United States Patent Office. ${ }^{43}$ During wartime the enforcement of the necessary secrecy statutes made inevitable some participation by personnel in governmental bureaus other than the Patent Office in the policing of pending applications, and the Patent Act contemplates some assistance by the Department of Agriculture in the examination of applications for patents upon the plants included as patentable subject matter. ${ }^{44}$ Nevertheless, the reporting provision of the Atomic Energy Act presents the first mandatory system of opening of the contents of applications filed in the Patent Office to a governmental agency that to some extent may be competing in research with the inventors whose applications are thus revealed. The segregation of functions within the Commission will doubtless insure that the use made of the disclosures will be confined to the restricted purpose for which access is given. The long record of respected confidence which the Patent Office has earned in this respect will undoubtedly be matched by equally meticulous observance of the proprieties by the Atomic Energy Commission.

\section{ADJUDICATIVE FUNCTIONS}

The Act imposes upon the Commission one function of a judicial character. It requires the Commission to designate a Patent Compensation Board, composed of two or more employees of the Commission, to pass upon applications for awards, just compensation, and the determination of reasonable royalties. ${ }^{45}$ The statute contains no details with respect to the organization and powers of the Board, except those just mentioned, but does set forth who the claimants may be, authorizes them to be rep-

${ }_{4} 60$ Stat. 768 (1946), 42 U.S.C.A. \$ I8II(a)(3) (Supp., r946).

4260 Stat. 768 (I946), 42 U.S.C.A. § I8II (d) (Supp., I946).

${ }^{43} 35$ U.S.C.A. Rule $5_{5}$ (App., 1940); Rule 120, Rules and Directions for Proceedings in the Patent Office (Aug. I, I869).

${ }_{44} 46$ Stat. 376 (1930), 35 U.S.C.A. $\$ 36 a$ (r940).

4560 Stat. 768 (I946), $4_{2}$ U.S.C.A. \& I8I I(e) (Supp., I946). 
resented by counsel, establishes the standards to be followed in making its determinations, and prescribes the judicial review available. $4^{6}$

I. Reasonable Royalties. The first function of the Patent Compensation Board is to pass upon applications, made either by the patent owner or licensee, for the determination of a reasonable royalty for patents involuntarily licensed by the declaration of the Commission that the patent is affected with the public interest. The Commission is empowered to set up its procedures by regulations. ${ }^{47}$

The standards prescribed by the Act for the determination of reasonable royalties require the Commission to consider all the defenses normally available in patent litigation, which include contentions that would invalidate the patent-as to which the licensee is estopped in ordinary patent litigation ${ }^{4}$-as well as the contribution to the development by federally financed research, the degree of utility, novelty, and importance of the invention (considerations applicable in the appraisal of liability in patent infringement suits), and the cost of the invention or patent to the owner. ${ }^{49}$ Except for the introduction of the opportunity to assail the validity of the patent, the standards prescribe no more than what would come within the province of a court of equity in making a determination of reasonable royalty, which is usually made upon the assumption that the parties are dealing at arm's length in a voluntary licensing effort. ${ }^{50}$

Review of either the determination of a reasonable royalty or an award discussed below is by petition in the Court of Appeals for the District of Columbia, upon the record made before the Commission, with the usual provision that "the findings of the Commission as to the facts, if supported by substantial evidence, shall be conclusive." The Court of Appeals is limited in its disposition to affirming the determination or setting it aside with a remand to the Commission. Review by application to the United States Supreme Court for a writ of certiorari is also provided.sx

2. Awards. The granting of awards under the Act is intrusted to the Patent Compensation Board, subject to the same provisions for review as in determinations of reasonable royalty, and pursuant to the same stand-

${ }_{46}^{6} 60$ Stat. 768,772 (r946), $4_{2}$ U.S.C.A. $\S \operatorname{I8II(e)(2),~(3),~and~(4);~§~I8r3(a)~(Supp.,~I946).~}$

${ }^{47} 60$ Stat. 763, 42 U.S.C.A. $\$$ I8II(e)(2) A (Supp., I946).

${ }^{48}$ Scott Paper Co. v. Marcalus Co., 326 U.S. 249 (I945); Westinghouse Electric Co. v. Formica Insulation Co., 266 U.S, 342 (I924).

4960 Stat. 768 (I946), 42 U.S.C.A. § I8II(c)(3) A (Supp., I946).

5o Austin-Western Road Machinery Co. v. Disc Grader \& Plow Co., 29r Fed. 30r, 304-5 (C.C.A. 8th, I923).

${ }^{s x} 60$ Stat. 768 (I946), 42 U.S.C.A. § I8II(e)(4) (Supp., I946). 
ards prescribed for reasonable royalties plus consideration of "the actual use made of such invention or discovery." "52

Because the provision for the eligibility to an award confines applicants to "any person making any invention or discovery useful in the production of fissionable material or in the utilization of fissionable material or atomic energy for a military weapon who is not entitled to compensation therefor under subsection (a) and who has complied with subsection (a) (3)," which relate to inventions rendered unpatentable by the Act and inventions required to be reported to the Commission, and the standards prescribed for the determination of the amount of the award include defenses to patentability, it may be urged that the invention or discovery upon which the application for the award is based must be one which would, except for the proscription of the Act, constitute a patentable invention. This reading of the provision would eliminate fundamental discoveries, and confine the award to those categories of invention embraced by the Patent Act. Practical applications of a simple engineering character might thus be given recognition while the underlying scientific work would be ignored. Such a limited interpretation of the Act would contradict its repeatedly expressed purpose to encourage research. A simple answer to the contended construction is that in enumerating the normal patent defenses among other considerations which the Commission shall respect in making determinations of reasonable royalty and amounts of award, the statute intended no more than that the enumerated defenses would be considered when applicable. This reading would serve the purposes of the Act, make the award possible for any invention or discovery in the prescribed field that merited recognition, and in no way interfere with the application of the specified standards in fixing the amount of the award.

3. Just Compensation. Probably the most difficult of the determinations assigned to the Patent Compensation Board of the Commission is that of assessing "just compensation" for revoked patent rights or for patent rights condemned or requisitioned by the Commission. With respect to the latter, the Commission retains control of what it may decide to purchase or take and can to that extent select its own burden. Exercise of the right to purchase or take will doubtless be guided by experience and by facts which dictate in some measure the need for the invention or patent as well as its value.

With respect to the patent rights revoked by the statute no such choice is available. The revoked rights will be of an infinite variety, some

${ }_{32} 60$ Stat. 768 (1946), 42 U.S.C.A. $\$$ I 8 II (e)(2)(c) and (3)(c) (Supp., I946). 
of complete patents upon processes or devices for producing fissionable material or its utilization in atomic weapons, others merely of partial rights dependent upon the extent of the use of the invention in such processes or devices, and still others merely of such rights as may be exercised in research or development activities. Since the revocation by the Act is final and the extent of potential use almost entirely speculative in many cases, the possibilities of injustice in assessing just compensation are infinite.

The standards prescribed by the Act for determining just compensation include the same considerations as are enumerated for determining awards, which add to the factors to be considered in fixing reasonable royalties "the actual use of" the invention or discovery. .3

The review available in just compensation cases is, probably because of the constitutional problem involved, different from that prescribed for reasonable royalty determinations and awards. The statute ${ }^{54}$ provides that any person dissatisfied with the amount fixed as just compensation by the Commission may collect half the amount fixed and then sue in the United States Court of Claims or in any federal district court for such further sum as would, added to the amount collected, constitute just compensation.

\section{CONCLUSION}

More than a year has passed since the passage of the Atomic Energy Act. Little evidence has appeared that the innovations in ordinary patent practices imposed by that Act will have any substantial effect favorable or unfavorable to the industrial economy or to the hopes for development of industrial applications of atomic energy expressed in that Act. The tentative and experimental character of the entire subject forbids the dogmatism that has characterized the literature of patent law. The scientific compulsion which has made this awesome impact upon the political, economic, and military attitudes of everyone compels a continuing, critical, and objective interest in such facts as experience with the law may yield.

5360 Stat. 768 (r946), 42 U.S.C.A. § $\mathrm{r} 8 \mathrm{II}(\mathrm{e})(3)$ (b) (Supp., r946).

5460 Stat. 772 ( 1946$), 42$ U.S.C.A. $\$$ r8r3(a) (Supp., I946). Note: For other discussion of the patent provision of the Atomic Energy Act see Report of Patent Advisory Panel to the Atomic Energy Commission (Sept., I947); Newman and Miller, Patents and Atomic Energy, I2 Law \& Contemp. Prob. 746 (I947); Miller, The First Official Report on A.E.C. Patent Problems, 4 Bulletin of the Atomic Scientists 77 (March, 1948). 